\title{
OPIEKA OKOŁOPORODOWA WE WSPÓŁCZESNYM POŁOŻNICTWIE
}

\author{
PERINATAL CARE IN THE CURRENT OBSTETRICS \\ Agnieszka Araszkiewicz ${ }^{1, a}$, Katarzyna Plagens-Rotman², b \\ ${ }^{1}$ Szkoła Rodzenia „Położna z Sercem” w Poznaniu \\ ${ }^{2}$ Państwowa Wyższa Szkoła Zawodowa im. Hipolita Cegielskiego w Gnieźnie \\ ${ }^{\text {a }}$ https://orcid.org/0000-0001-9464-7195 \\ ${ }^{\mathrm{b}} \mathrm{https}: / /$ orcid.org/0000-0001-7646-7430
}

DOI: https://doi.org/10.20883/pielpol.2020.26

\begin{abstract}
STRESZCZENIE
Wprowadzony 1 stycznia 2019 roku nowy standard opieki okołoporodowej niesie korzyści nie tylko dla samej kobiety, ale przynosi również znamienne zyski i zadania dla personelu medycznego. Zapewnia odpowiednią oraz jednakową organizację pracy przy jednoczesnym zagwarantowaniu bezpieczeństwa pacjentkom oraz personelowi, który postępuje według przyjętych standardów. Ponadto znacznie podnosi rangę zawodu położnej, wskazując jej miejsce w strukturze opieki nad ciążą fizjologiczną, porodem, połogiem oraz opieką nad noworodkiem.

Celem pracy było przedstawienie najciekawszych i najważniejszych aspektów, jakie przedstawiono w obowiązującym standardzie postępowania z kobietą ciężarną oraz rodzącą.

Zawód położnej jest zawodem samodzielnym podejmującym działania promujące aktywny poród, niefarmakologiczne metody łagodzenia bólu porodowego, a tym samym dążenie do ograniczenia medykalizacji.
\end{abstract}

SŁOWA KLUCZOWE: standard, położna, opieka okołoporodowa.

\section{Wstęp}

Zawód położnej jest uznany jako samodzielny. Położna udziela świadczeń zdrowotnych kobietom na przestrzeni poszczególnych okresów ich życia, najczęściej jednak sprawuje ona opiekę nad ciężarnymi, rodzącymi i położnicami [1].

Nowe spojrzenie na opiekę położnej w trakcie okresu okołoporodowego umożliwia Rozporządzenie Ministra Zdrowia z dnia 16 sierpnia 2018 roku w sprawie standardu organizacyjnego opieki okołoporodowej, który ma na celu zapewnienie kobiecie dostępu do najlepszej i jednakowej dla każdej pacjentki opieki w okresie ciąży, porodu i połogu [1-2]. Aby ułatwić realizację standardu stworzono wzory postępowań, które służą podejmowaniu świadomych decyzji przez przyszłych rodziców oraz zapewnią dostępność do opieki na naj-

\begin{abstract}
Introduced on 1st of January 2019, the new standard of the perinatal care brings benefits not only for the woman herself, but also significant profits and tasks for the medical personnel. It provides an appropriate and uniform work organization while guaranteeing the safety of the patients and the personnel who follow the accepted standards. In addition, it significantly raises the importance of the midwife's profession, indicating its place in the structure of care for physiological pregnancy, a childbirth, a puerperium and a newborn.

The purpose of the work was to present the most interesting and important aspects that were presented in the current standard of dealing with pregnant and delivery women.

The midwife's profession is an independent profession undertaking activities promoting active delivery, non-pharmacological methods of alleviating delivery pain and thus striving to reduce medicalisation.
\end{abstract}

KEYWORDS: standard, midwife, perinatal care.

wyższym możliwym poziomie. Standardy te zapewniają jednakowy schemat postępowania w każdym podmiocie wykonującym działalność leczniczą w zakresie opieki okołoporodowej oraz są podstawą do działań lekarzy i położnych sprawujących opiekę nad kobietą i jej dzieckiem. Przede wszystkim umożliwiają osiągnięcie dobrostanu matki oraz dziecka przy minimalnym korzystaniu z interwencji medycznych. Jak wskazuje ustawa: "Ingerencja w naturalny proces ciąży, porodu i laktacji wiąże się z uzasadnionym medycznie wskazaniem. Ingerencja w naturalny proces ciąży, porodu lub laktacji, w szczególności leczenie cukrzycy ciężarnej, nadciśnienia tętniczego i innych powikłań ciąży, lub poród zabiegowy, oznacza, że ciąża, poród lub laktacja wymagają zastosowania dodatkowych procedur wykraczających poza standard" [1]. 
Celem pracy było przedstawienie najciekawszych i najważniejszych aspektów, jakie przedstawiono w obowiązującym standardzie postępowania z kobietą ciężarną oraz rodzącą.

\section{Posiłki w trakcie porodu}

Jedną z ważniejszych kwestii w trakcie porodu jest możliwość przyjmowania posiłku przez rodzącą. W myśl nowych standardów „decyzję o możliwości spożywania posiłków przez rodzącą podejmuje osoba sprawująca opiekę nad rodzącą" [1, 3]. W związku z tym rekomendowane jest przyjmowanie potraw o niskiej zawartości tłuszczów, lekkich i łatwostrawnych, picie lekko słodkich napojów.

Kubli i wsp. [4] wykazali, że napoje izotoniczne zapobiegają rozwojowi ketozy u kobiety rodzącej, zwiększając pojemności żołądka. Ponadto w badaniu przeprowadzonym przez O'Sullivan i wsp. [5] nie stwierdzono ani jednego przypadku wystąpienia objawu Mendelsona u rodzącej, który związany jest z aspiracją treści żołądkowej do płuc.

\section{Poród rodzinny}

Narodziny dziecka to nie tylko wydarzenie medyczne, a przede wszystkim okoliczności o wielkim znaczeniu dla psychiki i tożsamości kobiety, przeżycie emocjonalne, a także jedno z najważniejszych wydarzeń rodzinnych. Jeśli istnieje taka możliwość, oboje rodziców chce w pełni cieszyć się nowym członkiem rodziny już od jego pierwszych chwil życia. Zadaniem personelu medycznego jest umożliwić rodzącej korzystanie ze wsparcia osoby bliskiej. Zwykle jest to partner pacjentki, ale podczas porodu towarzyszyć może też inna osoba z rodziny kobiety czy nawet przyjaciółka. Poręba [6] uważa, że: „Uczestnictwo ojca w porodzie przejawia się w jego działaniu. Zakres działania może być różnorodny, zależny od prezentowanej postawy wobec wspólnego porodu, jak również od oczekiwań kobiet rodzących". Wspólne przeżywanie aktu porodu wpływa pozytywnie na więzi partnerskie, szczególnie jeśli decyzja o uczestnictwie partnera podjęta została wspólnie z kobietą rodzącą. Ponadto ojcowie przygotowujący się do porodu rodzinnego odczuwają mniejszy lęk przed porodem [7]. Niedopuszczalne jest ograniczenie wyżej wspomnianego porodu rodzinnego tzn. brak akceptacji personelu medycznego na obecność osoby wskazanej przez samą pacjentkę.

Porody rodzinne zapoczątkowano we Francji w 1954 roku, a w Polsce pierwszy poród z udziałem ojca odbył się 10 czerwca 1983 roku w Łodzi w Klinice Perinatologii Akademii Medycznej. Znaczący udział w propagowaniu porodów rodzinnych należał jednak do Kliniki Położnictwa i Ginekologii Śląskiego Uniwersytetu Medycznego w Tychach, w której pierwsze porody rodzinne zaczęły odbywać się od 1987 roku. Obowiązujące standardy podkreślają pozytywne znaczenie porodu rodzinnego.

\section{Demedykalizacja}

Poród oraz laktacja to procesy fizjologiczne, które powinny być prowadzone zgodnie z naturą [1]. Przykładem demedykalizacji w Polsce, wprowadzonej w latach 20. ubiegłego wieku, jest nacięcie krocza, czyli zabieg położniczy często wykonywany rutynowo i bez wskazań medycznych [8]. „Osoba sprawująca opiekę rozpoznaje Il okres porodu, opierając się na obserwacji zachowania rodzącej, jej odczuć oraz wyniku badania położniczego wewnętrznego. W tym okresie porodu osoba sprawująca opiekę jest obowiązana do podjęcia, realizacji oraz udokumentowania [...] ochrony krocza, przy czym nacięcie krocza należy stosować wyłącznie w medycznie uzasadnionych przypadkach" [1].

Również Światowa Organizacja Zdrowia (WHO; ang. World Health Organization) zaleca ograniczenie stosowania nacięcia krocza, ze względu na szkodliwość jego rutynowego stosowania.

Drugim przykładem demedykalizacji są metody łagodzenia bólu w trakcie porodu. Mimo przybywających na rynku preparatów oraz metod farmakologicznych w myśl nowych standardów należy kierować się prawem natury.

Niefarmakologiczne metody łagodzenia bólu oraz poród z ochroną krocza zamiast rutynowego nacięcia przynoszą wiele korzyści matce oraz dziecku, negatywnych stron takich działań nie udowodniono [9-10].

Rodzącej podczas przyjęcia do szpitala należy przedstawić w sposób zrozumiały wszystkie możliwe metody łagodzenia bólu porodowego oraz poinformować o ich dostępności w danym podmiocie leczniczym [1-2]. Zastosowanie metod farmakologicznych podczas porodu wiąże się z dodatkowym monitorowaniem stanu zdrowia kobiety oraz płodu.

Pomoc w demedykalizacji stanowi utrzymanie odpowiedniej aktywności fizycznej rodzącej. Aktywność zapewnia nie tylko łagodzenie bólu, ale też wpływa na postęp porodu [11]. W myśl nowego standardu należy „zachęcać rodzącą do aktywności fizycznej i pomagać jej w znajdowaniu optymalnych dla niej pozycji podczas całego porodu" [1]. Rodząca w czasie porodu kieruje się swoim instynktem, spontanicznie zmienia pozycje ciała, tak by czuła się podczas porodu komfortowo. Pozycje przyjmowane przez rodzącą powinny być wybierane instynktownie. Zwykle są to pozycje wertykalne, w których kanał rodny skierowany jest w dół, co umożliwia działanie grawitacji, szybsze zstępowanie części przodującej i postęp porodu. Podmioty lecznicze powinny być wyposażone w sprzęt, który jest 
przydatny zarówno w czasie aktywności fizycznej pacjentki, jak i pomaga zapewnić jej odpowiedni odpoczynek w przerwie międzyskurczowej. Takim wyposażeniem są: stołki porodowe, piłki, liny oraz drabinki, które pomogą utrzymać ciało w pozycji pionowej $[1,11]$.

Znaczenie mają również metody fizjoterapeutyczne, np.: ciepłe bądź zimne okłady, masaż oraz, jeśli w danym szpitalu jest to dostępne, przezskórna stymulacja nerwowa TENS. W zależności od wyposażenia szpitala należy zasugerować skorzystanie z immersji wodnej pod prysznicem bądź w wannie [2, 12].

Obecny standard definiuje: metody farmakologiczne i niefarmakologiczne łagodzenia bólu porodowego, zakres współpracy personelu medycznego sprawującego opiekę nad rodzącą i jego kwalifikacje oraz odpowiedzialność za przebieg porodu z zastosowaniem tych metod.

\section{Wsparcie w okresie karmienia piersią}

W myśl nowego standardu każda kobieta w ciąży powinna jak najwcześniej zostać objęta opieką położnej podstawowej opieki zdrowotnej. Edukacja w Szkole Rodzenia powinna poruszać tematykę związaną z laktacją i rozwiązywaniem problemów występujących w tym okresie. Położna „zachęca matkę do karmienia naturalnego, udziela porady laktacyjnej z uwzględnieniem oceny anatomii i fizjologii piersi matki i jamy ustnej dziecka, oceny techniki karmienia, umiejętności ssania i skuteczności karmienia oraz czynników ryzyka niepowodzenia w laktacji, pomaga w rozwiązywaniu problemów związanych z laktacją" [1].

Podawanie mleka modyfikowanego powinno być prowadzone tylko za zgodą lekarza oraz matki po wcześniejszym poinformowaniu jej o takim sposobie żywienia dziecka. Ponadto zgodnie ze zmianami organizacyjnymi każda potrzebująca kobieta powinna mieć zapewniony sprzęt do skutecznego pozyskiwania mleka kobiecego (obowiązek od 1 stycznia 2022 roku). Jeśli noworodek urodzi się przedwcześnie i nie może być karmiony mlekiem matki, należy zapewnić mu pokarm z banku mleka kobiecego równolegle $z$ działaniami wspomagającymi stymulację laktacji u kobiety [2, 13-14].

Wsparcie w zakresie karmienia piersią powinno być wolne od treści i działań reklamowych związanych z preparatami do początkowego żywienia niemowląt, aby zminimalizować ryzyko przedwczesnej rezygnacji z karmienia naturalnego.

\section{Zaburzenia psychiczne jako czynnik ryzyka}

Dane epidemiologiczne wskazują, że 1 na 10 kobiet ma objawy depresji poporodowej w pierwszych 4-6 tygodniach po porodzie. Jedną z najważniejszych przyczyn takiego stanu jest spadek hormonów, ale też niepewność w jaki sposób „młoda mama” poradzi sobie w no- wej roli. Od stycznia 2019 roku lekarz lub położna ocenia zdrowie psychiczne kobiet za pomocą Skali Becka w pierwszym trymestrze ciąży, miesiąc przed porodem oraz w pierwszym miesiącu po porodzie. Na podstawie zaobserwowanych objawów depresji, zgłaszanych przez kobietę, powinna być ona skierowana na konsultację u specjalisty (psychologa lub psychiatry). Ostateczna decyzja dotycząca konsultacji u specjalisty należy do kobiety. Ważne jest, aby kobieta otrzymała informacje, czym jest depresja poporodowa i jakie są jej skutki, że objawy u niej występują i jakie może podjąć dalsze działania związane z leczeniem [1-2, 15].

\section{Rola położnej we współczesnej opiece okołoporodowej}

W opiece okołoporodowej nad kobietą ciężarną szczególną rolę spełnia położna [16]. Ważnym elementem działalności położnej w opiece okołoporodowej jest edukacja zdrowotna w zakresie przygotowania kobiety do życia w rodzinie, przekazywanie wiedzy niezbędnej na temat metod planowania ciąży oraz macierzyństwa i ojcostwa. „Ramowy program edukacji przedporodowej obejmuje okres prenatalny (ciąża), porodu, poporodowy (połóg) oraz wsparcie społeczne ciężarnej, położnicy i rodziny w okresie okołoporodowym" [1]. Ponadto położna powinna przekazać wiedzę na temat laktacji oraz zapewnić o możliwości rozwiązania problemów, jeśli jakieś pojawią się po porodzie. Zgodnie z nowymi standardami każda kobieta powinna znajdować się pod opieką położnej rodzinnej, która zapewni ciągłość opieki przed porodem oraz po rozwiązaniu w ramach wizyt patronażowych [1-2].

Poza działalnością medyczną i poradami z zakresu pielęgnacji do zadań położnej w czasie wizyt w okresie przedporodowym należy ocena możliwości wsparcia i pomocy ze strony osób z najbliższego otoczenia kobiety. Z racji sprawowania opieki w środowisku domowym jest jedną z pierwszych osób, które mogą zauważyć występowanie patologii w relacjach rodzinnych. W celu profilaktyki depresji poporodowej położna powinna posługiwać się skalą Becka [2, 15, 17].

W sali porodowej położna zobowiązana jest do stworzenia atmosfery wzajemnego zaufania oraz nawiązania porozumienia z rodzącą. Nadzór nad porodem naturalnym polega jedynie na obserwacji czynności serca płodu, postępu porodu oraz bezpieczeństwa dziecka oraz kobiety rodzącej. Rolą położnej jest również poinformowanie rodzącej o możliwości skorzystania z pozycji wertykalnych, immersji wodnej oraz innych metod łagodzenia bólu porodowego. Zachęca pacjentkę do zmian pozycji i aktywnego udziału w porodzie. Ponadto standardy opieki okołoporodowej nakładają obowiązek nawiązania z osobą towarzyszącą podczas 
porodu kontaktu, który powinien opierać się na poczuciu bezpieczeństwa, a przede wszystkim zachowaniu godności [1-2, 11, 13].

\section{Podsumowanie}

Zawód położnej jest zawodem samodzielnym, który w myśl nowego standardu okołoporodowego umożliwia położnej podejmowanie działań na rzecz aktywnego porodu, promowania niefarmakologicznych metod łagodzenia bólu porodowego, a tym samym prowadzi do ograniczenia medykalizacji.

\section{Piśmiennictwo}

1. Rozporządzenie Ministra Zdrowia z dnia 16 sierpnia 2018 r. w sprawie standardu organizacyjnego opieki okołoporodowej. Dz.U. 2018 poz.1756.

2. https://www.rodzicpoludzku.pl/Standard-opieki-okoloporodowej [data wejścia 29.04.2019].

3. O'Sullivan G, Liu B, Shennan AH. Oral intake during labor, Int Anesthesiol Clin. 2007; 45: 133-147.

4. Kubli M, Scrutton MJ, Seed PT, O'Sullivan G. An evaluation of isotonic "sport drinks" during labour. Anesth Analg. 2002; 94(2): 404-408.

5. O'Sullivan G, Liu B, Hart D, Seed P, Shennan A. Effect of food intake during labour on obstetric outcome: randomized controlled trial. BMJ. 2009; 338: 784.

6. Poręba R, Sioma-Markowska U. Analiza postaw ojców w porodzie rodzinnym w materiale Katedry i Oddziału Klinicznego Ginekologii i Położnictwa w Tychach w Śląskiej Akademii Medycznej. Perinatol Neonatol Ginekol. 2008; 2: 141-148.

7. Berkau A, Suchowiak S, Plagens-Rotman K. Poród rodzinny z perspektywy ojca dziecka. Pol Prz Nauk Zdr. 2016; 1 (46): 18-23.

8. Doroszewska A. Opieka okołoporodowa w Polsce po transformacji ustrojowej - między medykalizacją a demedykalizacją? Annales Universitatis Mariae Curie-Sklodowska, sectio I. 2016; 2: 47-59.

9. Bilińska E, Nowacka A, Dmoch-Gajzlerska E. Różnica między porodem naturalnym a zmedykalizowanym. Położ Nauka Prakt. 2016; 1: 14-16.

10. Sulima M, Golnik E. Alternatywne metody łagodzenia bólu porodowego. Technologie w optymalizacji opieki medycznej. EJMT. 2013; 1(1): 41-47.
11. Wawryków A, Korabiusz K, Fabian-Danielewska A, Niedzielska M, Janik I, Wawryków P. Physical activity of women during natural delivery. J Educ Health Sport. 2017; 7 (7): 927-939.

12. Smolarek N, Pięt M, Żurawska J, Szpunar R, Pięta B. Alternatywne sposoby łagodzenia bólu porodowego. Pol Prz Nauk Zdr. 2016; 1(46): 74-80.

13. Szajewska H, Horvath A, Rybak A, Socha P. Karmienie piersią. Stanowisko Polskiego Towarzystwa Gastroenterologii, Hepatologii i Żywienia Dzieci. Stand Med, Pediatr. 2016; 13: 9-24.

14. Bednarczyk M. Wsparcie laktacji i profesjonalna pomoc w karmieniu naturalnym, dla matek dzieci urodzonych przedwcześnie i z wadami anatomicznymi twarzoczaszki - na podstawie piśmiennictwa i własnego doświadczenia. Dev Period Med. 2016; 5: 358-371.

15. Maliszewska K, Świątkowska-Freund M, Bidzan M, Preis K. Ryzyko depresji poporodowej a cechy osobowości i wsparcie społeczne. Polskie przesiewowe badanie obserwacyjne matek 4 tygodnie i 3 miesiące po porodzie. Psychiatr Pol. 2017; 51(5): 889-898.

16. Smerdka A. Samodzielność i kompetencje zawodu położnej w systemie podstawowej opieki zdrowotnej w Polsce. Pol Prz Nauk Zdr. 2015; 1: 45-50.

17. Puszczałowska-Lizis E, Mokrzycka K, Jandziś S. Wpływ edukacji przedporodowej na przebieg ciąży, porodu i wczesne macierzyństwo. Med Ogólna Nauki Zdr. 2016; 22(4): 264-269.

Artykuł przyjęty do redakcji: 02.07.2019.

Artykuł przyjęty do publikacji: 26.02.2020.

Źródło finansowania: Praca nie jest finansowana z żadnego źródła. Konflikt interesów: Autorzy deklarują brak konfliktu interesów.

\author{
Adres do korespondencji: \\ Katarzyna Plagens-Rotman \\ ul. Ks. Kard. Stefana Wyszyńskiego 38 \\ 62-200 Gniezno \\ tel.: 614242942 \\ e-mail: plagens.rotman@gmail.com \\ Państwowa Wyższa Szkoła Zawodowa im. Hipolita Cegielskiego \\ w Gnieźnie
}

